\title{
Reseña de Moix (2018) Mi mente sin mí. Lo único que falta en tu vida eres tú
}

\author{
Santiago Estaún \\ Universitat Autònoma de Barcelona
}

Leer el prólogo de este libro te predispone positivamente no solamente hacia su autora presentándola como una persona sencilla, discreta, cercana sino también por el rigor científico y la capacidad pedagógica de la autora, para transmitir conocimientos profundos como son todo lo referente a nuestro cerebro y mente.

El libro en formato estándar consta de siete capítulos y un epílogo con agradecimientos y una seleccionada relación bibliográfica, con un total de 244 páginas. Publicado por Aguilar, 2018.

En el primer capítulo, Jenny Moix mediante un ejercicio práctico nos centra en el tema que quiere desarrollar: la dualidad mente y consciencia, o, yo y mente, como lo denomina ella. Dualidad que le permite introducir los aspectos instintivos, emocionales y mentales en cuanto son pensamientos e imágenes, los cuales perturban la capacidad atencional de
Moix, Jenny (2018). Mi mente sin mí. Lo único que falta en tu vida eres tú. Barcelona: Editorial Aguilar ISBN: 978-8403516496

focalizarse en la actividad que se realiza. Este proceso iniciático de conocimiento propio lo concluye con el "Conócete a ti mismo" del oráculo de Delfos.

En el segundo capítulo "La mente tiene vida propia", como indica el título, compara la actividad de la mente con símiles zoológicos para explicar esas interrupciones o reiteraciones de pensamientos que debemos aprender a controlar. Así, nos habla del mono que salta de una cosa a otra, del loro que repite la misma canción, del cuervo, del pájaro carpintero, para indicarnos que el pensamiento es una actividad propia del ser humano pero que debemos aprender a saber controlar.

El tercer capítulo lo titula "Las escapadas nocturnas de mi mente", con lo que nos está indicando que se adentra en el mundo onírico con toda su complejidad descriptiva, funcional e interpretativa. Este hecho le permite subrayar la dualidad consciente e inconscien- 
te o mente y yo, a la vez que indicar estrategias para que el yo pueda utilizar la actividad onírica de la mente.

Después de mostrar cómo nuestra mente está siempre activa y casi siempre sin nuestro control consciente, la autora presenta en el capítulo cuarto "Cómo guiar la mente", un conjunto de situaciones cuyo conocimiento puede facilitar el control de nuestros pensamientos de forma consciente y evitar caer en actitudes e incluso pensamientos que refuercen la creencia de que no podemos controlar nuestra mente. Y en el capítulo cinco "Cómo mimar la mente", pone el énfasis en los aspectos positivos a tener presentes para que ese control de la mente acabe siendo eficaz, para subrayar, en el capítulo sexto "Cuando la mente no molesta", los beneficios que aporta el saber controlar la mente, lo cual nos proporcionará y facilitará nuestra capacidad para hallar soluciones creativas, contemplar la belleza de las cosas pequeñas y las múltiples satisfacciones valorando los pequeños acontecimientos. Es en el capítulo séptimo "Lo que no debemos perder de vista", donde nos plantea cual es o ha de ser el centro en nuestra vida y, consecuentemente, vuelve a advertirnos de lo fácil que resulta cegarnos por cosas que no son esenciales y perseguir metas y objetivos que en realidad nos descentran.

En el epílogo del libro, la autora confiesa que después de hablar de la dualidad mente y yo observador, éste se le ha escapado y por ello habla del mismo en el epílogo del libro. Epílogo que, al intentar adentrarse en la actividad del yo consciente u observador, plantea el mayor tema de la persona humana: su trascendencia. El recorrido que realiza para intentar adentrase en lo que es la consciencia, ese yo observador, nos conduce a considerar las grandes experiencias místicas y, si nos es permitido, tomamos la expresión de Sta. Teresa de Jesús "vivo sin vivir en mí, y tan alta vida espero, que muero porque no muero", que bien resume esa dificultad de compren- der quien es ese yo consciente que todos tenemos y que de conformidad con los recientes conocimientos científicos parece que trasciende la misma neurología i/o biología que nos construye. Interrogantes planteados de trascendencia, espiritualidad e incluso en lenguaje junguiano de consciencia cósmica.

Ciertamente, una vez leído el libro debemos reconocer que el estilo personal y en primera persona que utiliza la autora, así como una narración expositiva directa, sencilla y de tono confidencial con el que nos describe hechos y acontecimientos personales unas veces $y$ de vivencias compartidas de amistades, otras, consigue que la lectura sea agradable y convincente. Efecto reforzado por el hecho que cada uno de los diferentes aspectos tratados en cada capítulo los comenta en un espacio que no supera generalmente las dos páginas, lo cual le da la sensación de ser una conversación personal entre la autora y el lector o sobre temas de nuestra vida cotidiana, situaciones personales, de amigos o de conocidos en las que se constata la actividad de la mente diferenciada del yo consciente u observador. Este hecho no desmerece el valor de las reflexiones y explicaciones de la actividad descontrolada de la mente, al apoyarse no sólo en estudios científicos, sino también en aquellos conocimientos de la sabiduría de personas que han demostrado una gran vida interior.

En el epílogo del libro, sin perder su estilo personal, directo y sencillo, la autora plantea el verdadero problema del yo consciente con el interrogante sobre la trascendencia de ese yo consciente u observador. Interrogante que supera la explicación basada en los procesos neuronales y abre la puerta a la mística y a la espiritualidad que hemos concretado en la frase de Sta. Teresa de Jesús, anteriormente mencionada y ante cuya realidad sólo hay la actitud del silencio contemplativo.

Santiago Estaún

SANTIAGO ESTAÚN

Profesor emérito de Psicología de la Percepción en la Universitat Autònoma de Barcelona. 


\section{DIRECCIÓN DE CONTACTO}

santiago.estaun@uab.cat

\section{FORMATO DE CITACIÓN}

Estaún, Santiago (2019). Reseña de Moix (2018) Mi mente sin mí. Lo único que falta en tu vida eres tú. Quaderns de Psicologia, 21(1), e1519. http://dx.doi.org/10.5565/rev/qpsicologia.1519 